\title{
Carbon footprint in different beef production systems on a southern Brazilian farm: a case study
}

\author{
Clandio F. Ruviaro ${ }^{\mathrm{a}, \mathrm{d}, *}$, Cristiane Maria de Léis ${ }^{\mathrm{b}, 1}$, Vinícius do N. Lampert ${ }^{\mathrm{c}, 1}$, \\ Júlio Otávio Jardim Barcellos ${ }^{\mathrm{d}}$, Homero Dewes ${ }^{\mathrm{d}, \mathrm{e}}$ \\ ${ }^{a}$ Agribusiness Postgraduate Program, FACE, UFGD, Dourados, Brazil \\ ${ }^{\mathrm{b}}$ Environmental Engineering Postgraduate Program, PPGEA, UFSC, Florianópolis, Brazil \\ ${ }^{\mathrm{c}}$ Brazilian Agricultural Research Corporation, EMBRAPA-CPPSUL, Bagé, Brazil \\ ${ }^{\mathrm{d}}$ Center for Research in Agribusiness, CEPAN, UFRGS, Porto Alegre, Brazil \\ ${ }^{\mathrm{e}}$ Biophysics Department, Biosciences Institute, UFRGS, Brazil
}

\section{A R T I C L E I N F O}

\section{Article history:}

Received 19 September 2013

Received in revised form

6 January 2014

Accepted 9 January 2014

Available online 22 January 2014

\section{Keywords:}

Life cycle assessment

GHG

Livestock

Meat

Environment

Consumer

\begin{abstract}
A B S T R A C T
The carbon footprint (CF) of beef production is one of the most widely discussed environmental issues within the current agricultural community due to its association with climate change. Because of these relevant and serious concerns, the beef cattle industry is under increasing pressure to reduce production or implement technological changes with significant consequences in terms of beef marketing. The goals of this study were to evaluate the CF per $1 \mathrm{~kg}$ of live weight gain (LWG) at the farm gate for different beef production systems in the southern part of Brazil. Aberdeen Angus beef-bred cattle were assigned to one of seven categories: natural grass; improved natural grass; natural grass plus ryegrass; improved natural grass plus sorghum; cultivated ryegrass and sorghum; natural grass supplemented with protein mineralised salt; and natural grass supplemented with protein-energetic mineralised salt. Monte Carlo analysis was employed to analyse the effect of variations of dry matter intake digestibility (DMID), total digestible nutrients (TDN) and crude protein (CP) parameters in methane $\left(\mathrm{CH}_{4}\right)$ enteric, $\mathrm{CH}_{4}$ manure, nitrous oxide $\left(\mathrm{N}_{2} \mathrm{O}\right)$ manure and $\mathrm{N}_{2} \mathrm{O} \mathrm{N}$-fertiliser. The method used was a comparative life cycle assessment (LCA) centred on the CF. The CF varied from $18.3 \mathrm{~kg} \mathrm{CO}_{2}$ equivalent $/ \mathrm{kg}$ LWG for the ryegrass and sorghum pasture system to $42.6 \mathrm{~kg} \mathrm{CO}_{2}$ equivalent/kg LWG for the natural grass system, including the contributions of cows, calves and steers. Among all grassland-based cattle farms, production systems with DMID from 52 to $59 \%$ achieved the lowest $\mathrm{CO}_{2}$ emissions and the highest feed conversion rate, thereby generating lower $\mathrm{CH}_{4}$ and $\mathrm{N}_{2} \mathrm{O}$ emissions per production system. Because the feed intake and feed conversion rate are one of the most important production parameters in beef cattle production with an obvious risk of data uncertainty, accurate feed data, which include quantity and quality, are important in estimates of CF for LWG. The choice of adequate feeding strategies to mitigate greenhouse gas (GHG) emissions may result in better environmental advantages.
\end{abstract}

(C) 2014 Elsevier Ltd. All rights reserved.

\section{Introduction}

Beef cattle production is one of the most important agricultural activities in Brazil and is characterised by a large number of animals and extensive pasture. The Brazilian beef industry is under

\footnotetext{
* Corresponding author. Universidade Federal da Grande Dourados, Programa de Pós-Graduação em Agronegócios (FACE) Rodovia Dourados-Itahum, Km 12, Dourados, MS CEP: 79800-000, Brazil. Tel./fax: +55 6734102063.

E-mail addresses: 00184298@ufrgs.br, clandioruviaro@ufgd.edu.br, clandioruviaro@hotmail.com (C.F. Ruviaro).

${ }^{1}$ Universidade Federal da Grande Dourados, Programa de Pós-Graduação em Agronegócios (FACE) Rodovia Dourados-Itahum, Km 12, Dourados, MS CEP: $79800-$ 000, Brazil. Tel./fax: +55 6734102063.
}

considerable pressure from national and international communities concerned with global warming based upon the notion that cattle production is responsible for over $50 \%$ of national greenhouse gas (GHG) emissions, which are directly related to the agricultural sector. From these emissions, $45 \%$ are caused by cattle enteric fermentation (methane, $\mathrm{CH}_{4}$ ), as well as urine and faeces decomposition, which releases nitrous oxide $\left(\mathrm{N}_{2} \mathrm{O}\right)$, and other less relevant gases (Bungenstab, 2012). The Brazilian herd has approximately 205 million heads occupying 170 million hectares of pasture according to a census of the Brazilian Institute of Geography and Statistics (IBGE, 2008).

In the southern Brazilian state of Rio Grande do Sul, there are approximately 13.2 million heads of cattle in 11.7 million hectares, 
which is approximately $53.7 \%$ of the total area of this state (IBGE, 2008). In this region, beef production relies on the management of natural pasture as the main source of animal feed. These grasslands exhibit high biodiversity and are characterised by high production and high nutritional quality during spring and summer but low production and low nutritional quality during autumn and winter when it is necessary to use cultivated pastures or supplementation as feed support. The regional pastures show more than 450 species of native grasses and approximately 150 species of legumes. Local biodiversity losses could affect the potential for sustainable animal and plant production in this region due to the loss of valuable species of natural forages, feed, food, ornamental and medicinal species and the reduction of environmental services provided by grassland vegetation, such as erosion control and soil carbon sequestration, which can mitigate climate change (Pillar et al., 2009). Thus, the local cattle industry is under scrutiny from both producers and the public.

In Brazil, approximately $70 \%$ of $\mathrm{CH}_{4}$ emissions are derived from cattle production (MCT, 2010). Most of the $\mathrm{CH}_{4}$ has its origin in enteric fermentation and is a physiological result of digestion in ruminant animals. These emissions represent, in part, the natural inefficient capture of energy contained in animal feed. The use of such techniques as the intensification of activity via the appropriate management of pastures and improved quality of food supplied to animals mitigates the production of GHG (Bungenstab, 2012; Harper et al., 1999; McAllister et al., 2011; O'Hara et al., 2003).

Thus, better pasture management, supplementary feeding practices, substitution of forage for food containing less fibre, adequate sanitary control, integrated management of animal wastes and the genetic improvement of animals are techniques that may improve livestock productivity and reduce emissions linked to beef cattle production (Barioni et al., 2007; Boadi et al., 2004; Iqbal et al., 2008; Oliveira et al., 2007; Pedreira et al., 2004; Segnini et al., 2007; Wilkins and Hump, 2003).

Emissions from cattle have been attributed to production processes that involve inputs (e.g., fertilisers and forage cultivation) and production itself $\left(\mathrm{CO}_{2}, \mathrm{CH}_{4}\right.$ and $\left.\mathrm{N}_{2} \mathrm{O}\right)$. Regarding the latter, $\mathrm{CH}_{4}$ emissions are produced by enteric fermentation and manure, and $\mathrm{N}_{2} \mathrm{O}$ emissions are emitted mostly by manure. There is also the potential use of nitrogen fertilisers in pastures emitting $\mathrm{N}_{2} \mathrm{O}$ (Luo et al., 2010). Among these GHG, the most important is $\mathrm{CH}_{4}$, due to the relatively large amount emitted (Beauchemin et al., 2008; Biswas et al., 2010; Steinfeld et al., 2006).

Seasonal changes in cattle production efficiency combined with the constant attention given by the media in highlighting beef cattle as a major source of GHG, has pushed for limitations of the cattle herds in an attempt to minimise their putative, negative and environmental effects. Analysis of the carbon footprint (CF) of cattle production identifies the production procedures or techniques in which emissions may be reduced using improved efficiencies, estimates the amount and breakdown of GHG emissions and provides a mechanism to track efforts in improving efficiencies and reducing emissions (Wiedmann and Minx, 2008).

The aim of this study was to quantify and analyse the variability of emissions, as CF per functional unit (FU), for typical southern Brazilian beef production systems with different options for animal feed intake data obtained from a beef cattle farm, and from Brazilian governmental reports and databases. For this purpose, we required definitions for (a) the typical beef production systems operating in southern Brazil; (b) the system boundary and functional unit to be applied; and (c) the dietary and scenario options to be considered in southern Brazilian beef production that may lead to reduced GHG emissions.

\section{Methods}

The contribution to climate change associated with seven different production systems was evaluated using a Life Cycle Assessment (LCA) approach (Finnveden et al., 2009; Guinée et al., 2001). This study uses LCA methodology to relate default data provided by Intergovernmental Panel on Climate Change (IPCC) (IPCC, 2007) for $\mathrm{CO}_{2}, \mathrm{CH}_{4}$, and $\mathrm{N}_{2} \mathrm{O}$ emissions related to feed and animal manure with data now available from the Brazilian Agricultural Research Corporation (EMBRAPA) (Lima et al., 2012; MCT, 2010).

In the inventory analysis phase, inputs from the environment (resources used) and outputs to the environment (emissions) associated with the product were considered. In the impact assessment phase, inputs and outputs were interpreted in terms of Global Warming Potential (GWP).

\subsection{Definition of the production system}

This study was performed at a farm in the Western Frontier region of the state of Rio Grande do Sul (Fig. 1), in the Southern part

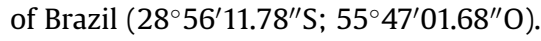

This Western Frontier region has a large beef cattle herd (ca. $3,300,000$ heads), which is approximately $22 \%$ of the total cattle herd in this state (IBGE, 2008). The climatic classification of the region is wet subtropic Cfa in Koeppen classification (Koeppen, 1948), and the average precipitation is $1598 \mathrm{~mm} / \mathrm{year}$, without periodical dry seasons. The average annual temperature is $19.8^{\circ} \mathrm{C}$. Cattle are bred extensively; the herds forage on natural and cultivated pasture with variable stocking rates, and they are the source for most of the meat production in this region.

In addition to natural grass, other pastures for beef cattle feed include improved natural grass (a mixture of natural grass, ryegrass and clover), and ryegrass and sorghum. In the farm analysed, all farmed animals are of the Bos taurus breed (Aberdeen angus). It was assumed that calves are weaned at approximately 180 days and that from this period onwards, the animals graze on grass. From 180 days to when the fattening weight is attained, the animals are allowed to graze on grass according to the scenarios described in Section 2.2. The animal fattening weight was $430 \mathrm{~kg}$ live weight for all the scenarios.

The data used in this paper are the average of data collected during six years of observation of 420 animals in different cattle

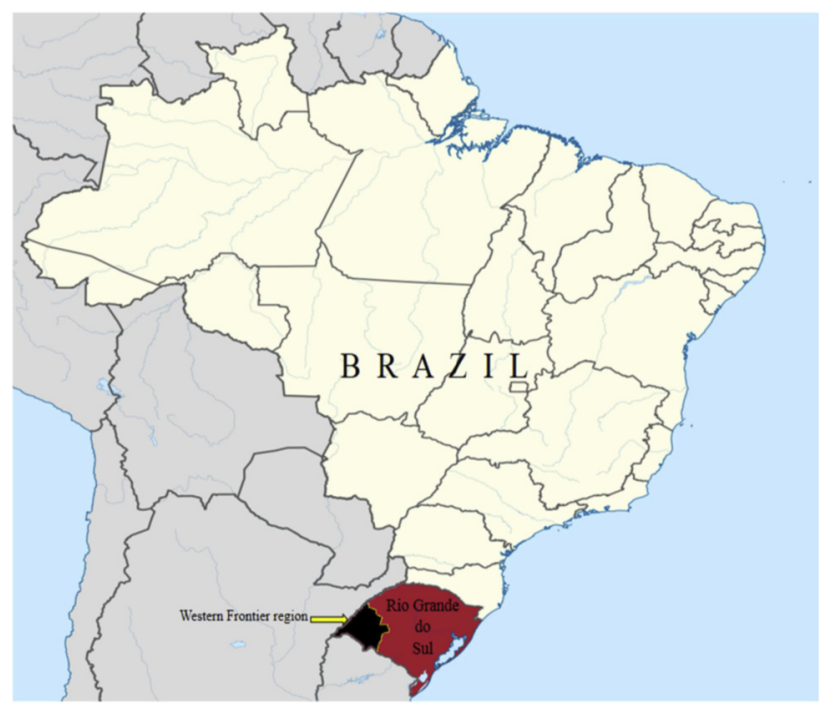

Fig. 1. Geographical position of Rio Grande do Sul. Source: GoogleMaps (2013). 
production systems that are commonly used in the region. Analysed data in this case study were related to São Lucas Farm (São Borja city) that has a pastoral surface of 2,370 ha (ha), an occupancy of 1,800 animal units (A.U.) and it has a productivity of $139 \mathrm{~kg}$ live weight/ha. Besides, it has marketed $306,000 \mathrm{~kg}$ live weight/year resulting in an annual income circa US\$400,000. Moreover, the farm continuously has been specializing in intensive livestock system.

\subsection{Description of scenarios}

In this study, the scenarios used were developed using Angus beef-bred animals utilised in typical Southern Brazilian beef production systems as castrated males. The scenarios were designed according to the different feeding regimens that the animals were raised upon (Table 1 ).

These scenarios were chosen because they represent the most frequently used beef cattle production systems in the region. The system was modified to consider the life cycle from pregnant cows (281 days) to fattened steers with a $430 \mathrm{~kg}$ final live weight in all scenarios. Changes in the number of days required for each animal to reach the final live weight, under the different scenarios were due to the differences in the nutritional quality of the animals' respective diets.

The amount of synthetic $\mathrm{N}$-fertiliser applied in scenario II, III, IV and $\mathrm{V}$ was $12.5,105,85$ and $165 \mathrm{~kg}$ of N/hectare, respectively.

Differences in the nutritional quality of the diets occurred in the same and in different scenarios. The effects of the variability in the quality of the same ingredient in the emission of GHG were obtained by examining the interval of typical values for each ingredient within each scenario (Table 2).

Within each scenario, in the different scenarios, and in every age-related animal category, the values changed for live weight, live weight gain, interval from calving to fattening, and stock rate (Table 2).

Several nutritional factors have been identified in the literature, which affect the rate of enteric $\mathrm{CH}_{4}$ production in beef cattle; the key factors are related to DM intake, DM digestibility, and animal productivity (Merino et al., 2011).

\subsection{Data source}

The data considered in this work were gathered during a period of six consecutive years (from 2005 to 2011). A model based on the nutrient requirements and metabolism of animals of different beef production systems was used to quantify the CF. The method used a cradle to farm-gate approach substantiated on life cycle assessment principles whereby all relevant inputs and outputs from the beef production system were included, with the system boundaries set as shown in Fig. 2.

Primary inputs included animal feed (mineralised salt, energetic salt and protein-energetic salt), and electricity and fuel for forage

Table 1

Description of scenarios, productions systems and period of grazing.

\begin{tabular}{lll}
\hline Scenarios & Production systems & Period (days) \\
\hline I & Natural grass & 840 \\
II & Improved natural grass & 510 \\
III & Natural grass/ryegrass & $510 / 159$ \\
IV & Improved natural grass/sorghum & $360 / 125$ \\
V & Cultivated ryegrass and sorghum & 502 \\
VI & Natural grass supplemented & 660 \\
& with protein mineralised salt & \\
VII & Natural grass supplemented with & 510 \\
& protein-energetic mineralised salt & \\
\hline
\end{tabular}

Table 2

Values for live weight, live weight gain, interval from calving to fattening, and stock rate used to estimate the GHG emissions of cattle production in different nutritional scenarios.

\begin{tabular}{|c|c|c|c|c|c|c|c|}
\hline \multirow[t]{2}{*}{ Scenarios } & & \multicolumn{5}{|c|}{ Age, mo } & \\
\hline & & 6 & 12 & 18 & 24 & 30 & \\
\hline & Live weight, kg & & & & & & \\
\hline I & & 165 & 195 & 280 & 325 & 430 & \\
\hline II & & 190 & 330 & 430 & - & - & \\
\hline III & & 165 & 195 & 280 & 430 & - & \\
\hline IV & & 190 & 330 & 430 & - & - & \\
\hline V & & 190 & 330 & 430 & - & - & \\
\hline VI & & 220 & 260 & 360 & 430 & - & \\
\hline VII & & 220 & 260 & 430 & - & - & \\
\hline & Live weight gain, kg & & & & & & Total \\
\hline I & & 133 & 30 & 85 & 45 & 105 & 398 \\
\hline II & & 158 & 140 & 100 & - & - & 398 \\
\hline III & & 133 & 30 & 85 & 150 & - & 398 \\
\hline IV & & 158 & 140 & 100 & - & - & 398 \\
\hline V & & 158 & 140 & 100 & - & - & 398 \\
\hline VI & & 188 & 40 & 100 & 70 & - & 398 \\
\hline VII & & 188 & 40 & 170 & - & - & 398 \\
\hline & $\begin{array}{l}\text { Interval from calving } \\
\text { to fattening, } d\end{array}$ & & & & & & \\
\hline I & & 180 & 150 & 180 & 150 & 180 & 840 \\
\hline II & & 180 & 180 & 150 & - & - & 510 \\
\hline III & & 180 & 150 & 180 & 159 & - & 669 \\
\hline IV & & 180 & 180 & 125 & - & - & 485 \\
\hline $\mathrm{V}$ & & 180 & 180 & 142 & - & - & 502 \\
\hline VI & & 180 & 150 & 180 & 150 & - & 660 \\
\hline VII & & 180 & 150 & 180 & - & - & 510 \\
\hline & $\begin{array}{l}\text { Live weight supported, } \\
\mathrm{kg} / \mathrm{ha}\end{array}$ & & & & & & Means \\
\hline I & & 397 & 397 & 397 & 397 & 397 & 397 \\
\hline II & & 716 & 716 & 716 & - & - & 716 \\
\hline III & & 397 & 397 & 397 & 930 & - & 530 \\
\hline IV & & 716 & 716 & 1150 & - & - & 861 \\
\hline V & & 930 & 930 & 930 & - & - & 930 \\
\hline VI & & 380 & 380 & 388 & 380 & & 382 \\
\hline VII & & 380 & 380 & 380 & - & - & 380 \\
\hline
\end{tabular}

soil preparation and transportation of mineralised salt to farm. Secondary inputs included chemicals (fertilisers and pesticides) applied to forage, and fuel for forage practices and agrochemical manufacture. The nutrient requirements of individual animals were calculated using the Nutrient Requirements of Beef Cattle (NRC, 2000). Animal diets were formulated to provide the feed requirements of the animals within each subsystem according to body weight, sex and live weight gain. The CF was assessed by comparing the annual inputs and outputs under each scenario in the same period (days) and was expressed per live weight gain (LWG). Land use change was not taken into account in any of the scenarios and potential changes in soil carbon were ignored due to the current lack of relevant Southern Brazilian data.

\subsection{The system boundary}

The system boundary was defined by the GHG emissions associated with Southern Brazilian beef production from "cradle to farm-gate" (Fig. 2).

The LCA of the production systems included natural grass, cultivated forages (natural grass plus ryegrass and clover, ryegrass, or sorghum), natural grass supplemented with protein-energetic mineralised salt and the resources used to produce these components (e.g., diesel and fertilisers), and all transportation effects, including the transport of components to the farm where they were consumed by the herd. Data concerning resource use and emissions associated with the production and delivery of the inputs for forage cultivation (fertilisers, diesel, and agricultural machinery) were 


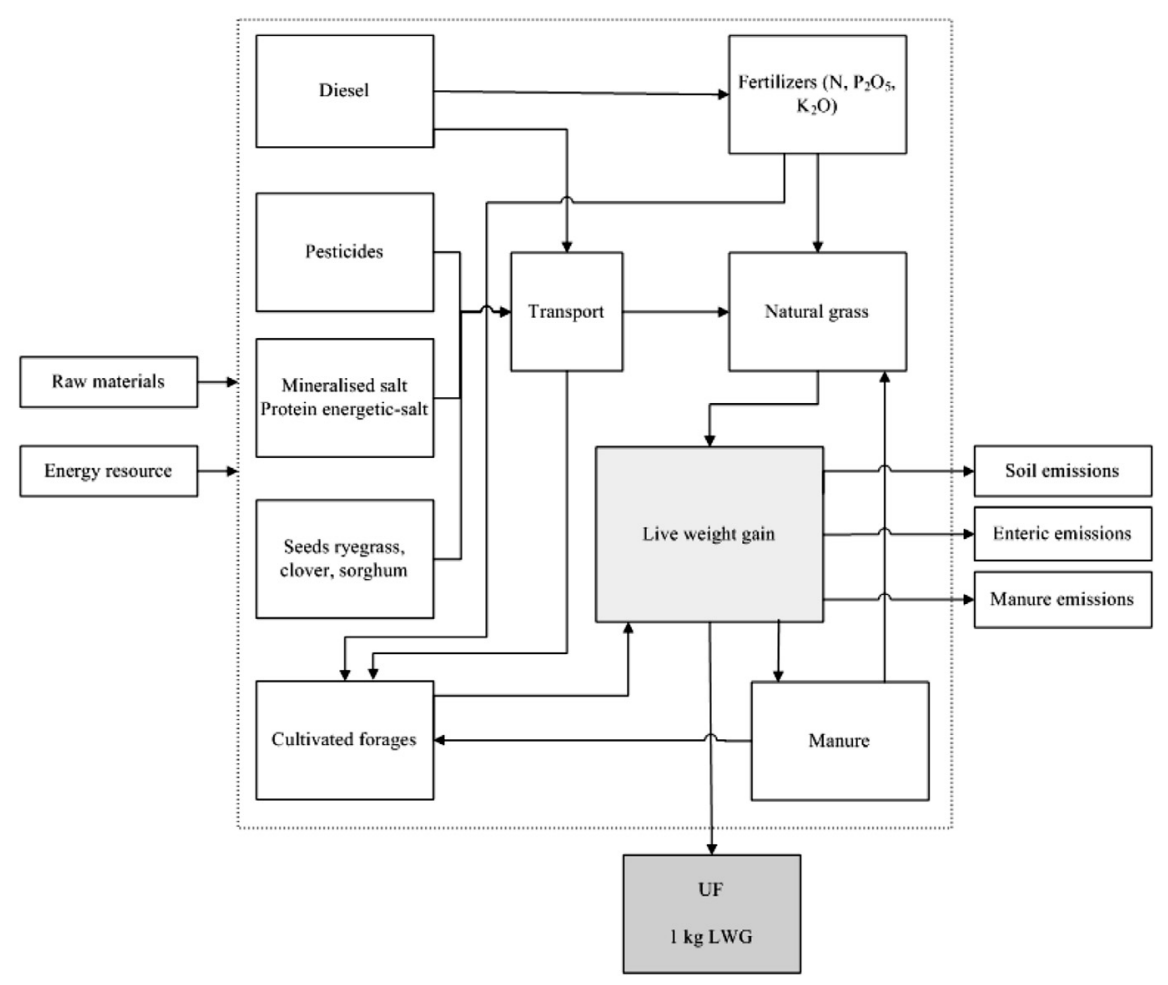

Fig. 2. System Boundaries of Southern Brazilian beef production from "cradle to farm-gate".

obtained from the Ecoinvent database, version 3.0 (Nemecek et al., 2007).

The model included the physical limits of beef unit and associated activity: emissions associated with nitrogen fertiliser production, transportation and delivery into the soil; emissions associated with animals; and emissions associated with the diesel used for agricultural work on the farm. The following GHG sources were considered: on-farm $\mathrm{CH}_{4}$ emissions from cattle and manure; on-farm $\mathrm{N}_{2} \mathrm{O}$ emissions from manure and soils; and run-off and volatilisation of indirect $\mathrm{N}_{2} \mathrm{O}$ emissions. The emissions associated with the production of medicines and pesticides were excluded due to the lack of available data (Cederberg and Mattsson, 2000). $\mathrm{CO}_{2}$ from enteric fermentation was excluded from the study because this gas was considered neutral with respect to GHG emissions (IPCC, 2007).

\subsection{Functional unit and allocation}

Comparisons of beef production systems demands consistent FU. In this study, the FU used for all flows within each system studied was " $1 \mathrm{~kg}$ live weight gain at the farm gate". This FU was a measure of the performance of a production system in which all inputs and outputs were related (ISO, 2006b). This FU became one of the most used environmental protection indicators of animal production (Galli et al., 2012; Lam et al., 2010).

\subsection{Impact category}

In this study, we analyse the CF related to global warming. The GWP over a 100 years-time horizon was used to determine the contribution of $\mathrm{CO}_{2}, \mathrm{CH}_{4}$ and $\mathrm{N}_{2} \mathrm{O}$ to the greenhouse effect (IPCC, 2007). Among different categories of environmental impacts, the CF has received the most current attention (Wiedmann and Minx, 2008). The CF was estimated for the average regional beef production using a standardised method of LCA (ISO, 2006a, 2006b) to calculate the environmental impact of a product from a life cycle perspective. The CF estimation using LCA (Crosson et al., 2011; Cuček et al., 2012) considers the resources used in production, as well as the production of gases during the production process (Peters et al., 2010). Calculations were performed using the LCA software tool SimaPro 7.3.2 (PRéConsultants, 2010). These gases have different GWP when converted to carbon dioxide equivalents $\left(\mathrm{CO}_{2}\right)$, which is a metric measure used to compare emissions from various GHG in which the GWP is based. Each $\mathrm{kg}$ of $\mathrm{CO}_{2}, \mathrm{CH}_{4}$ and $\mathrm{N}_{2} \mathrm{O}$ released into the atmosphere is equivalent to $1 \mathrm{~kg}, 25 \mathrm{~kg}$ and $298 \mathrm{~kg}$ of carbon dioxide, respectively (IPCC, 2007). The analyses of other impact categories in the beef cattle industry in Brazil are currently hindered by the lack of reliable sources of data.

\subsection{Emission factors}

Enteric $\mathrm{CH}_{4}$ emissions were calculated using the equations obtained from IPCC (Dong et al., 2006). The input data in this model were the animal live weights, which were used to estimate the energy required for maintenance, and the beef yield to estimate the energy required for meat production. In addition, the energy content in feed intake, and the proportions of roughage feed and crude protein in the total dry matter intake (DMI) were used to estimate the $\mathrm{CH}_{4}$ and $\mathrm{N}_{2} \mathrm{O}$ emissions (Dong et al., 2006; NRC, 2000).

Emission factors (EFs) for $\mathrm{N}_{2} \mathrm{O}$ from manure were based on data obtained from Primavesi et al. (2012). Over the duration of each life cycle stage in all production systems, the environmental inventory was limited to emissions of enteric $\mathrm{CH}_{4}$ and soil manure, $\mathrm{CH}_{4}, \mathrm{~N}_{2} \mathrm{O}$ emissions from urea, and $\mathrm{N}_{2} \mathrm{O}$ emissions from manure. The emissions from animals were calculated according to the data obtained from chapter 10 of the IPCC (Dong et al., 2006) using equations $10.21,10.23,10.24,10.25$ (Table 3) and Table 10.17.

Methane emissions from manure and excreta deposited on the field during grazing were calculated according to Tier 2 protocols from the IPCC guidelines (IPCC, 2007). The emission factors and 
Table 3

Equation used and reference source to animal emissions.

\begin{tabular}{|c|c|c|}
\hline Source & Equation & References \\
\hline Equation $10.21 / \mathrm{CH}_{4}$ emission factors for enteric fermentation & $\mathrm{EF}=[\mathrm{GE} \times(\mathrm{Ym} / 100) \times 365 / 55.65]$ & Dong et al. (2006) \\
\hline Equation $10.23 / \mathrm{CH} 4$ emission factor from manure management & $\mathrm{EF}_{(\mathrm{T})}=\left(\mathrm{VS}_{(\mathrm{T})} \times 365\right) \times\left[\mathrm{B}_{\mathrm{o}(\mathrm{T})} \times 0.67 \mathrm{~kg} / \mathrm{m}^{3} \times \sum \mathrm{s}, \mathrm{k} \mathrm{MCF}_{\mathrm{S}, \mathrm{k}} / 100 \times \mathrm{MS}_{(\mathrm{T}, \mathrm{S}, \mathrm{k})}\right]$ & Dong et al. (2006) \\
\hline Equation $10.24 /$ Volatile solid excretion rates & $\mathrm{VS}=[\mathrm{GE} \times(1-\mathrm{DE} \% / 100)+(\mathrm{UE} \mathrm{GE})] \times[(1-\mathrm{ASH} / 18.45)]$ & Dong et al. (2006) \\
\hline Equation 10.25/Direct $\mathrm{N}_{2} \mathrm{O}$ emissions from manure management & $\mathrm{N}_{2} \mathrm{O}_{\mathrm{D}(\mathrm{mm})}=\left[\sum \mathrm{s}\left[\sum_{\mathrm{T}}\left(\mathrm{N}_{(\mathrm{T})} \times \mathrm{Nex}_{(\mathrm{T})} \times \mathrm{MS}_{(\mathrm{T}, \mathrm{S})}\right)\right] \times \mathrm{EF}_{3(\mathrm{~S})}\right] \times 44 / 28$ & Dong et al. (2006) \\
\hline
\end{tabular}

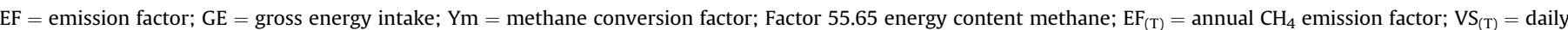

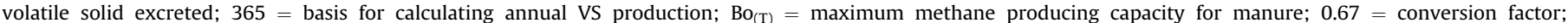

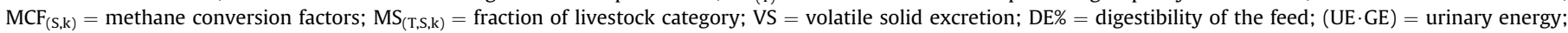

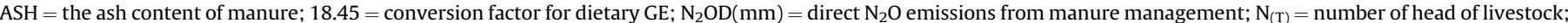

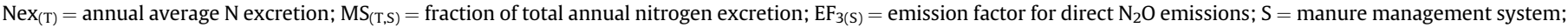
$\mathrm{T}=$ species/category of livestock; $44 / 28=$ conversion of $\left(\mathrm{N}_{2} \mathrm{O}-\mathrm{N}\right)(\mathrm{mm})$ emissions to $\mathrm{N}_{2} \mathrm{O}(\mathrm{mm})$ emissions.

methane conversion factors (MCFs) were calculated following Tier 2 protocols and adjusted following the analysis protocols in Lima et al. (2006) and MCT (2010). Tier 2 protocols were employed to calculate the enteric methane emissions due to the sensitivity of the emissions to the production system and the importance of methane emissions to the overall GHG emissions in beef cattle production. In this study, a $6 \%$ conversion factor (Ym) was applied to the pasture data (Dong et al., 2006; Johnson and Johnson, 1995; Primavesi et al., 2012). The production of manure was calculated based on the DMI with digestibility varying according to the forage type in each production system (Peripolli et al., 2011; Valadares Filho et al., 2010).

Direct emissions of $\mathrm{N}_{2} \mathrm{O}$ from soil and $\mathrm{EF}$ values were calculated as recommended by the IPCC (2007) with adjustments as previously described in Alves et al. (2012) using equations 11.2 and 11.5 from chapter 11 with the measured nitrogen intake and nitrogen retained (Table 4).

The nitrogen applied to the soil as fertiliser was calculated as nitrogen in urea, as recommended by SBCS (2004). The nitrogen in excreta was calculated as the total amount of $\mathrm{N}$ in feed DMI subtracted from the amount of $\mathrm{N}$ in beef (calves and growth). The indirect emissions of $\mathrm{N}_{2} \mathrm{O}$ caused by the volatilisation of ammonia $\left(\mathrm{NH}_{3}\right)$ and leaching of nitrate $\left(\mathrm{NO}_{3}\right)$ were estimated using EF values according to the IPCC (2007).

\subsection{Monte Carlo analysis}

To capture the inherent variability of ingredients in beef cattle production systems in this study, we used Monte Carlo analysis (MC). This tool simulates a probable range of outcomes given a set of variable conditions and can be applied within a risk assessment or Life Cycle Inventory framework to capture parameter variability (Huijbregts et al., 2001; Miller et al., 2006; Henriksson et al., 2011). Thus, MC is a technique employed to quantify variability and uncertainty using probability distributions. The effect of variations in the production data on the $\mathrm{CF}$ was analysed using $\mathrm{MC}$ analysis based on 5000 iterations, in which the probability distribution of $\mathrm{CF}$ was estimated for Brazilian beef cattle. The MC analysis was performed using @Risk of Palisade Corporation and SimaPro 7.3. Because no data bank on the nutritional data of the diet used was currently available, to the best of our knowledge, a triangular distribution was assumed for all parameters in the analysis.

\section{Results and discussion}

The evaluation of strategies for mitigation and adaptation usually occurs at scales at which interventions can be performed (e.g., production system, region, country). Recent publications have reported the use of LCA to determine all or a portion of the GHG emissions from the measured inputs and outputs related to beef production systems (Avery and Avery, 2008; Beauchemin et al., 2011; Cederberg et al., 2011; Dollé et al., 2011; McAllister et al., 2011; Schils et al., 2007; Sejian et al., 2011; Place and Mitloehner, 2012; Veysset et al., 2010).

The application of and comparisons among existing LCA studies may be limited due to differences in goals, system boundaries or functional units. Creating LCA models that account for different management strategies and technologies is critical because there is increasing consumer interest in sustainable beef production, as well as a need for a complete analysis of these different systems.

The parameters used in the analysis were Dry Matter Intake Digestibility (DMID), Total Digestible Nutrients (TDN), and Crude Protein (CP) because they exhibit a close interrelation with $\mathrm{CH}_{4}$ enteric, $\mathrm{CH}_{4}$ manure, $\mathrm{N}_{2} \mathrm{O}$ manure, and $\mathrm{N}_{2} \mathrm{O} \mathrm{N}$-fertiliser emissions (Table 5). This information on DMID, TDN and CP was calculated for each diet in each scenario according to the NRC (2000), Peripolli et al. (2011), and Valadares Filho et al. (2010).

In the seven scenarios analysed (Table 1 ), the $\mathrm{CF}$ was predominantly affected by $\mathrm{CH}_{4}$ emissions ranging from 86 to $98 \%$, which were mostly related to the beef cattle themselves. MC analysis was used to analyse the effect of the variations of DMID, TDN and CP parameters in $\mathrm{CH}_{4}$ enteric, $\mathrm{CH}_{4}$ manure, $\mathrm{N}_{2} \mathrm{O}$ manure and $\mathrm{N}_{2} \mathrm{O} \mathrm{N}$ fertiliser. This was performed using the software @Risk. The mean and variability of the GHG was employed to calculate the CF using SimaPro 7.3 (Table 6).

Considering the data shown in Tables $2-4$, the results obtained from the MC simulation may denote a low uncertainty using variations in DMID, TDN and CP for the scenarios examined.

The reason for the moderate differences in $\mathrm{CH}_{4}$ enteric (Fig. 3) was due to the forage and grass quality variation for the DMID (Table 5), which was attributed to the specificity of the scenarios analysed. The $\mathrm{N}_{2} \mathrm{O} \mathrm{N}$-fertiliser emissions oscillated from $57 \%$ to $82 \%$ of total $\mathrm{N}_{2} \mathrm{O}$ emissions considering the amount of $\mathrm{N}$ synthetic fertiliser applied ranging from 85 to $165 \mathrm{~kg} / \mathrm{ha}$ in scenarios III, IV and $\mathrm{V}$.

Table 4

Equation used and reference source to manage soils and pasture.

\begin{tabular}{|c|c|c|}
\hline Source & Equation & References \\
\hline Equation 11.2 /Direct $\mathrm{N}_{2} \mathrm{O}$ emissions from managed soils & $\mathrm{N}_{2} \mathrm{O}_{\text {Direct }}-\mathrm{N}=\sum \mathrm{i}\left(\mathrm{F}_{\mathrm{SN}}+\mathrm{F}_{\mathrm{ON}}\right)_{\mathrm{i}} \times \mathrm{EF}_{1 \mathrm{i}}+\left(\mathrm{F}_{\mathrm{CR}}+\mathrm{F}_{\mathrm{SOM}}\right) \times \mathrm{EF}_{1}+\mathrm{N}_{2} \mathrm{O}-\mathrm{N}_{\mathrm{OS}}+\mathrm{N}_{2} \mathrm{O}-\mathrm{N}_{\mathrm{PRP}}$ & $\operatorname{IPCC}(2007)$ \\
\hline $\begin{array}{l}\text { Equation } 11.5 / \mathrm{N} \text { in urine and dung deposited by grazing } \\
\text { animals on pasture }\end{array}$ & $\mathrm{F}_{\mathrm{PRP}}=\sum_{\mathrm{T}}\left[\left(\mathrm{N}_{(\mathrm{T})} \times \mathrm{Nex}_{(\mathrm{T})}\right) \times \mathrm{MS}_{(\mathrm{T} . \mathrm{PRP})}\right]$ & IPCC (2007) \\
\hline
\end{tabular}

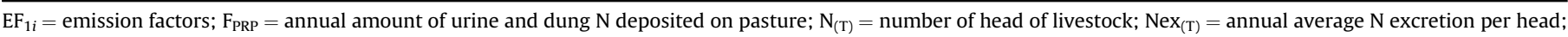
$\mathrm{MS}_{(\mathrm{T}, \mathrm{PRP})}=$ fraction of total annual $\mathrm{N}$ excretion for each livestock species/category. 
Table 5

Values for Dry Matter Intake Digestibility (DMID), Total Digestible Nutrients (TDN), and Crude Protein (CP) used as the main drivers of enteric CH4 emissions and energy utilisation efficiency of cattle production in different nutritional scenarios.

\begin{tabular}{|c|c|c|c|c|c|c|c|c|c|}
\hline \multirow[t]{2}{*}{ Scenarios } & \multicolumn{3}{|c|}{ DMID (\%) } & \multicolumn{3}{|c|}{ TDN (\%) } & \multicolumn{3}{|c|}{$\mathrm{CP}(\%)$} \\
\hline & Min. & Mean & Max & Min. & Mean & Max & Min. & Mean & Max \\
\hline I & 34.31 & 45.33 & 53.81 & 50.28 & 58.23 & 62.91 & 6.73 & 8.30 & 10.89 \\
\hline II & 54.57 & 63.74 & 73.98 & 56.21 & 63.33 & 68.80 & 9.71 & 15.50 & 20.82 \\
\hline III & 39.55 & 50.50 & 58.99 & 50.80 & 59.67 & 65.13 & 8.07 & 10.41 & 12.98 \\
\hline IV & 46.86 & 56.92 & 66.35 & 55.26 & 63.50 & 69.58 & 9.96 & 14.83 & 19.26 \\
\hline V & 46.55 & 56.39 & 65.76 & 47.15 & 54.66 & 61.78 & 7.07 & 9.17 & 10.95 \\
\hline VI & 34.43 & 45.33 & 53.74 & 50.20 & 58.23 & 62.90 & 6.73 & 8.30 & 10.89 \\
\hline VII & 34.31 & 45.33 & 53.76 & 50.26 & 58.23 & 62.94 & 6.73 & 8.30 & 10.89 \\
\hline
\end{tabular}

The feed intake from the pasture was likely the most uncertain parameter when considering beef production. This parameter was very significant for production systems with a high intake of forage or grass from animal grazing. If carbon sequestration in pastures was included in the $\mathrm{CF}$ estimates and if strategies used to reduce GHG emissions were discussed, then it is necessary to improve the knowledge concerning pasture feed intake.

The estimated CF ranged from 18.30 to $42.60 \mathrm{~kg} \mathrm{CO}$-e/ $\mathrm{kg} \mathrm{LWG}$ for a complete beef cattle system, including the contributions of cows, calves, and steers (Table 7).

The MC analysis provided data with $97.5 \%$ confidence interval for each scenario. Using the average, the ranking was scenario I, VI, III, VII, IV, II and V. However, the Monte Carlo analysis showed that there were situations in which the scenario II, IV, V and VII could change the position in this ranking (Table 7). Because feed intake and the feed conversion rate were one of the most important production parameters in beef cattle production with an obvious risk of data uncertainty, accurate feed data, including quantity and quality, were important in estimates of CF for the LWG.

The results indicated that when examined on an equal liveweight production basis, scenario I (natural grass), with $42.6 \mathrm{~kg}$ $\mathrm{CO}_{2}$-e/kg LWG, was more greenhouse gas-intensive than scenario $\mathrm{V}$ (cultivated ryegrass and sorghum) with $20.0 \mathrm{~kg} \mathrm{CO}_{2}$-e/ $\mathrm{kg}$ LWG. The least $\mathrm{CO}_{2}$-e emitting production systems were scenario $\mathrm{V}$ and II, with 20.0 and $20.2 \mathrm{CO}_{2}-\mathrm{e} / \mathrm{kg}$ of LWG, respectively, which produced fattened animals in 485 and 510 days, respectively. These results were close to those reported by Phetteplace et al. (2001), who estimated $15.5 \mathrm{~kg} \mathrm{CO}_{2}$-e/ $\mathrm{kg}$ live weight for calf-to-beef systems. Our results were also similar to estimates obtained by Casey and Holden (2006) and Veysset et al. (2010) of 11 and $15 \mathrm{~kg}$ of $\mathrm{CO}_{2}$-e/ $\mathrm{kg}$ of live weight gain, respectively. Hacala and Le Gall (2006) estimated a CF between 11.33 and $14.69 \mathrm{~kg} \mathrm{CO}-\mathrm{e} / \mathrm{kg}$ live weight in three suckler systems. Studies evaluating the CF of beef production in Japan (Ogino et al., 2004), Sweden (Koneswaran and Nierenberg, 2008) and Brazil (Cederberg et al., 2009), also reported similar values of total GHG emissions to our current study, ranging from $22,8 \mathrm{~kg}$ of $\mathrm{CO}_{2}-\mathrm{e} / \mathrm{kg}$ of beef to $32.3 \mathrm{~kg}$ of $\mathrm{CO}_{2}-\mathrm{e} / \mathrm{kg}$ of beef.
The highest $\mathrm{CO}_{2}$-e emissions were from scenarios I and VI. These scenarios produced an average of 42.6 and $33.3 \mathrm{~kg} \mathrm{CO}$-e/ $\mathrm{kg} \mathrm{LWG}$, respectively, with fattening periods of 840 and 660 days, respectively. These scenarios had the lowest DMID with an average value of $34.37 \%$. Among all the grassland-based cattle farms, production systems with DMID from 52 to $59 \%$ achieved the lowest $\mathrm{CO}_{2}-\mathrm{e}$ emissions and highest feed conversion rate. This indicated that they generated lower $\mathrm{CH}_{4}$ and $\mathrm{N}_{2} \mathrm{O}$ emissions per production system.

Importantly, it would be necessary to consider the relative intensity of the production system, stocking rate (number of animals raised and produced per hectare) and kilogramme of body weight gain obtained per hectare as the main drivers of the greenhouse gases emissions. The most intensive production systems, i.e., production systems with scenarios II, IV, V and VII with 510, 485, 485 and 510 days for producing fattened animals and a stocking rate of $716,861,930$ and $380 \mathrm{~kg} / \mathrm{ha}$, respectively, had the lowest $\mathrm{CO}_{2}$-e emitting scenarios (Table 1 ).

Scenario VII produced lower emissions (23.4 kg CO 2 -e/kg LWG) despite the low DMID (45.33\%). This was due to the proteinenergetic mineralised salt used because it acts as an amender in the feed conversion rate and reduces the time to achieve the fattening weight (510 days). These results were consistent with those of other studies demonstrating that higher quality forage, the use of concentrated, essential oils or increased growth rates reduced methane and nitrous oxide emitted from manure, both of which are key emission gases (Benchaar and Greathead, 2011; Casey and Holden, 2006; Lovett et al., 2005).

Comparisons of these results with those obtained in previous studies revealed a number of difficulties. First, in Brazil, there are only a few studies on beef production using the Life Cycle Assessment methodology (Ruviaro et al., 2012). One very significant problem is the variation in choice of functional unit and time scale among studies (de Vries and de Boer, 2010). For example, a study of a Japanese beef fattening system (Ogino et al., 2004) estimated a $32.3 \mathrm{~kg} \mathrm{CO}$-e $/ \mathrm{kg}$ of beef gain during the fattening of the animal, but this did not include cow emissions for the entire system. Furthermore, the production efficiency in the Japanese cattle system was very different from that observed in this study.

In another study of Brazilian beef cattle, Cederberg et al. (2011) estimated a CF from beef cattle production in the Legal Amazon Region. However, the estimates provided by Cederberg et al. were not sufficient for comparison because they assumed calving intervals of 20 months and 3-4 years to fattening. This is a production system that is used in a specific region and does not represent Brazilian norms. Thus, these issues make it difficult to compare the results of our study to those of Cederberg et al. (2011) due to differences in management practices and in the assumptions regarding the production systems. The corresponding regions of the studies were completely different in terms of soil, weather conditions, management, pasture, animal genetics, and other factors. Despite the large differences among studies, reflecting

Table 6

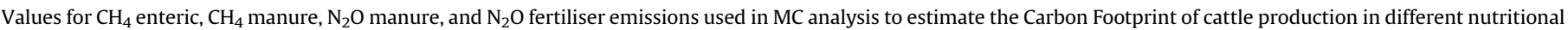
scenarios.

\begin{tabular}{|c|c|c|c|c|c|c|c|c|c|c|c|c|}
\hline \multirow[t]{2}{*}{ Scenarios } & \multicolumn{3}{|c|}{$\mathrm{CH}_{4}$, enteric } & \multicolumn{3}{|c|}{$\mathrm{CH}_{4}$, manure } & \multicolumn{3}{|c|}{$\mathrm{N}_{2} \mathrm{O}$, manure } & \multicolumn{3}{|c|}{$\mathrm{N}_{2} \mathrm{O}$, fertiliser } \\
\hline & Min. & Mean & Max & Min. & Mean & Max & Min. & Mean & Max & Min. & Mean & Max \\
\hline I & 0.28443 & 0.32705 & 0.43526 & 0.00272 & 0.00276 & 0.00278 & 0.00101 & 0.00131 & 0.00182 & - & 0.00000 & - \\
\hline II & 0.18370 & 0.21336 & 0.26662 & 0.00184 & 0.00186 & 0.00188 & 0.00076 & 0.00120 & 0.00160 & 0.00017 & 0.00023 & 0.00031 \\
\hline III & 0.22681 & 0.26287 & 0.35344 & 0.00258 & 0.00261 & 0.00263 & 0.00089 & 0.00126 & 0.00171 & 0.00124 & 0.00167 & 0.00237 \\
\hline IV & 0.17482 & 0.20206 & 0.24859 & 0.00172 & 0.00174 & 0.00176 & 0.00070 & 0.00108 & 0.00144 & 0.00412 & 0.00498 & 0.00628 \\
\hline V & 0.16889 & 0.20450 & 0.26413 & 0.00177 & 0.00179 & 0.00181 & 0.00061 & 0.00095 & 0.00123 & 0.00133 & 0.00173 & 0.00238 \\
\hline VI & 0.26463 & 0.30570 & 0.41247 & 0.00254 & 0.00257 & 0.00260 & 0.00118 & 0.00149 & 0.00200 & - & 0.00000 & - \\
\hline VII & 0.22618 & 0.26188 & 0.35578 & 0.00221 & 0.00223 & 0.00225 & 0.00093 & 0.00116 & 0.00153 & - & 0.00000 & - \\
\hline
\end{tabular}



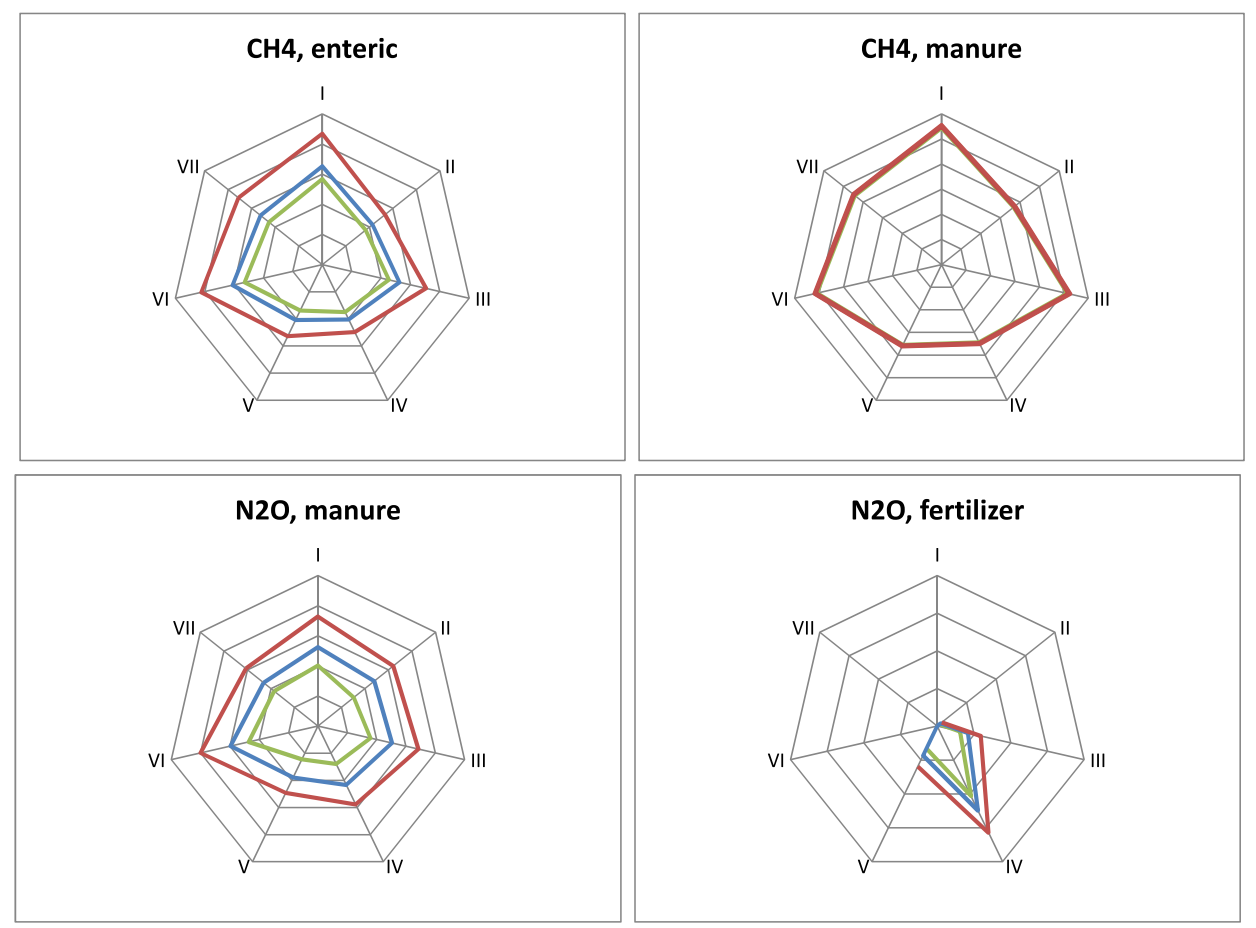

Fig. 3. Variability of estimated of greenhouse gas emissions $\left(\mathrm{CH}_{4}\right.$ enteric, $\mathrm{CH}_{4}$ manure, $\mathrm{N}_{2} \mathrm{O}$ manure and $\mathrm{N}_{2} \mathrm{O}$ fertiliser) to the functional unit.

differences in the boundaries of the systems and assumed farming practices, our results were consistent with those of Pelletier et al. (2010). They considered a complete beef production system in which the fattening phase (more than 12 months) accounted for less than $36 \%$ of the total GHG emissions in the most efficient scenarios, similar to scenarios II, IV, V and VII of the current study and are the lowest $\mathrm{CO}_{2}$-e emitting scenarios. The growth phase between calving and 6 months of age accounted for less than $19 \%$ of the total $\mathrm{CO}_{2}-\mathrm{e}$ emissions in all these scenarios.

Considering the variation among published studies from the perspective and specific methodology of collection and analysis of data, we recognise that the results from specific regions cannot be used to compare beef production scenarios in different regions of the world. A comparison of various studies emphasises the effect of each production system and variation in efficiency on the estimated environmental impact.

\section{Conclusions}

The results show that improved natural grass (II) and cultivated ryegrass and sorghum (V) production systems have lower GHG

Table 7

Summary of the calculated $\mathrm{CO}_{2}$ equivalent inputs from each growth stage of each scenario.

\begin{tabular}{llllll}
\hline \multirow{2}{*}{ Scenarios } & \multicolumn{5}{l}{$\mathrm{CO}_{2}$ equivalent, $\mathrm{kg} \mathrm{CO}$-e/kg live weight gain } \\
\cline { 2 - 5 } & Min. & Mean & Max. & s.d $^{\mathrm{a}}$ & $\mathrm{CV} \%^{\mathrm{b}}$ \\
\hline I & 39.3 & 42.6 & 46.5 & 1.79 & 4.21 \\
II & 18.7 & 20.2 & 22.0 & 0.85 & 4.18 \\
III & 27.2 & 29.6 & 32.6 & 1.42 & 4.80 \\
IV & 21.1 & 23.4 & 25.4 & 1.04 & 4.44 \\
V & 18.3 & 20.0 & 21.8 & 0.91 & 4.52 \\
VI & 30.6 & 33.3 & 36.6 & 1.56 & 4.68 \\
VII & 21.1 & 23.4 & 26.1 & 1.26 & 5.40 \\
\hline
\end{tabular}

a Standard deviation.

b Coefficient of variation is the average variance of the mean value. emissions (20.2 and $20.0 \mathrm{~kg} \mathrm{CO}$-e/ $\mathrm{kg}$ live weight gain) than other (e.g., natural grass with $42.6 \mathrm{CO}_{2}$-e/ $\mathrm{kg}$ live weight gain) beef cattle production systems in the western frontier of the state of Rio Grande do Sul, Brazil. A modification in the quality of feed expressed in the variability of DMID, TDN and CP can alter the results and ranking positions of the scenarios concerning $\mathrm{CF}$ for live weight gain.

Furthermore, the generalisation of these conclusions to any other region of Brazil must consider the great heterogeneities in the country in terms of climate conditions, soil, natural grasses, cultivated forages, animal genetics, management, greenhouse gases emissions, biodiversity and many other aspects and differences in the local animal production systems.

Besides, the current trends in terms of the number of publications, channelling resources for research, governmental demands and generation of a growing volume of organised data on GHG flow suggest that the use of LCA to quantify the potential environmental impact of products from agricultural and livestock production and to support public policy will be an area of intense development in the near future.

Brazil continues to lack consolidated studies regarding the development of LCA and life cycle inventories of production processes and systems for the balancing of GHGs and other environmental impact categories. However, several groups from national institutions (e.g., the Federal University of Rio Grande do Sul, the University of São Paulo and EMBRAPA) have made consistent progress in the evaluation of emission factors based on national data as well as the evaluation and reparameterisation of process models developed abroad using national databases.

In addition, there has been recent progress towards the production of integrated models for scenario projection and assessment at a national level. Furthermore, the integration of dynamic mathematical models in methods of Life Cycle Assessment in Brazilian cattle production should soon be possible. However, a basic condition for this to occur is the construction of geographical databases of biophysical conditions, land use, prices and infrastructure. 
Considering the lack of baseline data in Brazil as a whole, this study can support future LCA studies concerning livestock and agriculture issues in this country.

\section{Acknowledgements}

Coordination of Improvement of High Education Personnel CAPES and Brazilian Science and Technology National Council CNPq, Brazil.

\section{References}

Alves, B.J.R., Carvalho, A.M., Jantalia, C.P., Madari, B.E., Urquiaga, S., Santos, J.C.F., et al., 2012. Nitrous oxide and nitric oxide emissions in agricultural soil. In: Lima, M.A., Boddey, R.M., Alves, B.J.R., Machado, P.L.O., Urquiaga, S. (Eds.), Carbon Stocks and Greenhouse Gases Emissions in Brazilian Agriculture. Embrapa, Brasília, pp. 159-191.

Avery, A., Avery, D., 2008. Beef production and greenhouse Gas emissions. Environ. Health Perspect. 116, A374-A375.

Barioni, L.G., Lima, M.A., Zen, S., Guimarães Júnior, R., Ferreira, A.C., 2007. A baseline projection of methane emissions by the Brazilian beef sector: preliminary results. In: Greenhouse Gases and Animal Agriculture Conference. Christchurch, New Zealand.

Beauchemin, K.A., Janzen, H.H., Little, S.M., McAllister, T.A., McGinn, S.M., 2011. Mitigation of greenhouse gas emissions from beef production in western Canada - evaluation using farm-based life cycle assessment. Animal Feed Sci. Technol. 166-167, 663-677.

Beauchemin, K.A., Kreuzer, M., O’Mara, F., McAllister, T.A., 2008. Nutritional management for enteric methane abatement: a review. Aust. J. Exp. Agric. 48, 21-27.

Benchaar, C., Greathead, H., 2011. Essential oils and opportunities to mitigate enteric methane emissions from ruminants. Animal Feed Sci. Technol. 166-167, 338355.

Biswas, W.K., Graham, J., Kelly, K., John, M.B., 2010. Global warming contributions from wheat, sheep meat and wool production in Victoria, Australia - a life cycle assessment. J. Clean. Prod. 18, 1386-1392.

Boadi, D.C., Benchaar, C., Chiquette, J., Massé, D.I., 2004. Mitigation strategies to reduce enteric methane emissions from dairy cows: update review. Can. J. Animal Sci. 84, 319-335.

Bungenstab, D.J., 2012. Brazilian Beef Cattle: Reducing Global Warming by the Production Systems Efficiency. Documents/Embrapa Gado de Corte. Embrapa, Brasília, p. 38.

Casey, J.W., Holden, N.M., 2006. Quantification of GHG emissions from sucker-beef production in Ireland. Agric. Syst. 90, 79-98.

Cederberg, C., Mattsson, B., 2000. Life cycle assessment of milk production - a comparison of conventional and organic farming. J. Clean. Prod. 8, 49-60.

Cederberg, C., Meyer, D., Flysjo, A., 2009. In: SIK (Ed.), Life Cycle Inventory of Greenhouse Gas Emissions and Use of Land and Energy in Brazilian Beef Production. The Swedish Institute for Food and Biotechnology, Swedish.

Cederberg, C., Persson, U.M., Neovius, K., Molander, S., Clift, R., 2011. Including carbon emissions from deforestation in the carbon footprint of Brazilian beef. Environ. Sci. Technol. 45, 1773-1779.

Crosson, P., Shalloo, L., O’Brien, D., Lanigan, G.J., Foley, P.A., Boland, T.M., Kenny, D.A., 2011. A review of whole farm systems models of greenhouse gas emissions from beef and dairy cattle production systems. Animal Feed Sci. Technol. 166-167, 29-45.

Cuček, L., Klemeš, J.J., Kravanja, Z., 2012. A Review of Footprint analysis tools for monitoring impacts on sustainability. J. Clean. Prod. 34, 9-20.

de Vries, M., de Boer, I.J.M., 2010. Comparing environmental impacts for livestock products: a review of life cycle assessments. Livest. Sci. 128, 1-11.

Dollé, J.B., Agabriel, J., Peyraud, J.L., Faverdin, P., Manneville, V., Raison, C., Gac, A., Le Gall, A., 2011. Greenhouse gases in cattle breeding: evaluation and mitigation strategies. Les. gaz à effet de serre en élevage bovin: Évaluation et leviers d'action 24, 415-432.

Dong, H., Magino, J., McAllister, T.A., Hatfield, J.L., Johnson, D.E., Lassey, K.R., Lima, M.A., Romanovskaya, A., 2006. Emissions from livestock and manure management. In: Eggleston, H.S., Buendia, L., Miwa, K., Ngara, T., Tanabe, K. (Eds.), 2006 IPCC Guidelines for National Greenhouse Gas Inventories Programme. Institute for Global Environmental Strategies, Hayama, pp. 10.1110.87.

Finnveden, G., Hauschild, M.Z., Ekvall, T., Guinée, J., Heijungs, R., Hellweg, S., Koehler, A., Pennington, D., Suh, S., 2009. Recent developments in life cycle assessment. J. Environ. Manag. 91, 1-21.

Galli, A., Wiedmann, T., Ercin, E., Knoblauch, D., Ewing, B., Giljum, S., 2012. Integrating ecological, carbon and water footprint into a "Footprint Family" of indicators: definition and role in tracking human pressure on the planet. Ecol. Indic. 16, 100-112.

Guinée, J.B., Gorre, M., Heijungs, R., Hippes, G., Kleijn, R., Koning, A., Oers, L.v., Sleeswijk, A.W., Suh, S., Haes, H.A.U., 2001. In: Guinée, J.B. (Ed.), Life Cycle Assessment: An Operational Guide to the ISO Standards. Centre of Environmental Science. Leiden university (CML).
Hacala, S., Le Gall, A., 2006. Evaluation of greenhouse emissions from breeding cattle and prospects for mitigation. Fourrages 186.

Harper, L.A., Denmead, O.T., Freney, J.R., Byers, F.M., 1999. Direct measurements of methane emissions from grazing and feedlot cattle. J. Animal Sci. 77, 13921401.

Henriksson, M., Flysjö, A., Cederberg, C., Swensson, C., 2011. Variation in carbon footprint of milk due to management differences between Swedish dairy farms. Animal 5, 1474-1484.

Huijbregts, M.A.J., Norris, G.A., Bretz, R., Ciroth, A., Maurice, B., Bahr, B. V. Weidema, B., de Beaufort, A.S.H., 2001. Framework for modeling data uncertainty in life cycle inventories. Int. J. Life Cycle Assess. 6, 127-132.

IBGE, 2008. IBGE Automatic System Recovery - SIDRA. Brazilian Institute of Geography and Statistics.

IPCC, 2007. Guidelines for National Greenhouse Gas Inventories. 2006. Intergovernmental Panel on Climate Change.

Iqbal, M., Cheng, Y.F., Zhu, W.Y., Zeshan, B., 2008. Mitigation of ruminant methane production: current strategies, constraints and future options. World J. Microbiol. Biotechnol. 24, 2747-2755.

ISO, 2006a. ISO 14040: Environmental Management - Life Cycle Assessment Principles and Framework. ISO copyright office, Geneva.

ISO, 2006b. ISO 14044: Environmental Management - Life Cycle Assessment Requirements and Guidelines. ISO copyright office, Geneva.

Johnson, K.A., Johnson, D.E., 1995. Methane emissions from cattle. J. Animal Sci. 73, 2483-2492.

Koeppen, W., 1948. Climatology: In a Study of the Climates Land. Economic Culture Fund, Mexico.

Koneswaran, G., Nierenberg, D., 2008. Beef production: Koneswaran and Nierenberg respond. Environ. Health Perspect. 116, A375-A376.

Lam, H.L., Varbanov, P.S., Klemes, J.J., 2010. Minimising carbon footprint of regional biomass supply chains. Resour. Conserv. Recycl. 54, 303-309.

Lima, M.A., Boddey, R.M., Alves, B.J.R., Machado, P.L.O., Urquiaga, S., 2012. Carbon Stocks and Greenhouse Gases Emissions in Brazilian Agriculture. Embrapa, Brasília.

Lima, M.A., Pessoa, M.C.P.Y., Ligo, M.A.V., 2006. First Brazilian Inventory from Anthropogenic Greenhouse Gases Emissions. Reports. Embrapa - Brazilian Agricultural Research Corporation, Brasilia.

Lovett, D., Stack, L., Lovell, S., Callan, J., Flynn, B., Hawkins, M., O’Mara, F., 2005 Manipulating enteric methane emissions and animal performance of latelactation diary cows through concentrate supplementation at pasture. J. Dairy Sci. 88, 2836-2842.

Luo, J., de Klein, C.A.M., Ledgard, S.F., Saggar, S., 2010. Management options to reduce nitrous oxide emissions from intensively grazed pastures: a review. Agric. Ecosyst. Environ. 136, 282-291.

McAllister, T.A., Beauchemin, K.A., McGinn, S.M., Hao, X., Robinson, P.H., 2011 Greenhouse gases in animal agriculture-Finding a balance between food production and emissions. Animal Feed Sci. Technol. 166-167, 1-6.

MCT, 2010. Anthropogenic Emissions and Removals Inventory of Greenhouse Gases Not Controlled by the Montreal Protocol - Initial Communication from Brazil. Part II. Ministry of Science and Technology, Brasília.

Merino, P., Ramirez-Fanlo, E., Arriaga, H., del Hierro, O., Artetxe, A., Viguria, M., 2011 Regional inventory of methane and nitrous oxide emission from ruminant livestock in the Basque Country. Animal Feed Sci. Technol. 166-167 (0), 628640.

Miller, S.A., Landis, A.E., Theis, T.L., 2006. Use of Monte Carlo analysis to characterize nitrogen fluxes in agroecosystems. Environ. Sci. Technol. 40 (7), 2324-2332.

Nemecek, T., Kagi, T., Blaser, S., 2007. Life cycle inventories of agricultural production systems. Final report ecoinvent. In: Inventories. S.C.f.L.C., Dübendorf, CH.

NRC, 2000. Nutrient Requirements of Beef Cattle. Subcommitte on Beef Cattle Nutrition, Committe on Animal Nutrition, p. 248.

O’Hara, P., Freney, J., Uliatt, M., 2003. Abatement of Agricultural Non-carbon Dioxide Greenhouse Gas Emissions: A Study of Research Requirements. Ministeria Group on Climate Change, the Minister of Agriculture and the Primary Industries Council. Ministry of Agriculture and Forestry on Behalf of the Convenor, New Zealand, p. 170.

Ogino, A., Kaku, K., Osada, T., Shimada, K., 2004. Environmental impacts of the Japanese beef-fattening system with different feeding lengths as evaluated by a life-cycle assessment method. J. Animal Sci. 82, 2115-2122.

Oliveira, S.G., Berchielli, T.T., Pedreira, M.S., Primavesi, O., Frighetto, R., Lima, M.A., 2007. Effect of tannin levels in sorghum silage and concentrate supplementation on apparent digestibility and methane emission in beef cattle. Animal Feed Sci. Technol. 135, 236-248.

Pedreira, M.S., Berchielli, T.T., Oliveira, S.G., Primavesi, O., Lima, M.A., Frighetto, R. 2004. Methane production and concentration of rumen volatile fatty acids in steers fed different ratios of forage: concentrate. In: SBZ (Ed.), Annual Meeting of the Brazilian Society of Animal Science. Embrapa, Campo Grande.

Pelletier, N., Pirog, R., Rasmussen, R., 2010. Comparative life cycle environmental impacts of three beef production strategies in the Upper Midwestern United States. Agric. Syst. 103, 380-389.

Peripolli, V., Prates, E.R., Barcellos, J.O.J., Neto, J.B., 2011. Fecal nitrogen to estimate intake and digestibility in grazing ruminants. Animal Feed Sci. Technol. 163, $170-176$.

Peters, G.M., Wiedemann, S.G., Rowley, H.V., Tucker, R.W., 2010. Accounting for water use in Australian red meat production. Int. J. Life Cycle Assess. 15, $311-$ 320. 
Phetteplace, H.W., Johnson, D.E., Seidl, A.F., 2001. Greenhouse gas emissions from simulated beef and dairy livestock systems in the United States. Nutrient Cycl. Agroecosystems 60.

Pillar, V. de P., Müller, S.C., Castilhos, Z.M. de S., Jacques, A.V.A., 2009. Southern Grassland: Conservation and Sustainable Use of Biodiversity. MMA, Brasília, p. 403.

Place, S.E., Mitloehner, F.M., 2012. Beef production in balance: considerations for life cycle analyses. Meat Sci. 92, 179-181.

PRéConsultants, 2010. Simapro 7.3 (The Netherlands).

Primavesi, O., Berndt, A., Lima, M.A., Frighetto, R., Demarchi, J.J.A.A., Pedreira, M.S. 2012. Greenhouse gases production in agricultural systems: methane emissions bases inventory by ruminants. In: Lima, M.A., Boddey, R.M., Alves, B.J.R. Machado, P.L.O. (Eds.), Carbon Stocks and Greenhouse Gases Emissions in the Brazilian Agricultural. SCT and Embrapa Meio Ambiente, Brasília, pp. 239-270.

Ruviaro, C.F., Gianezini, M., Brandao, F.S., Winck, C.A., Dewes, H., 2012. Life cycle assessment in Brazilian agriculture facing worldwide trends. J. Clean. Prod. 28 $9-24$.

SBCS, 2004. In: Manual of Fertilization and Liming for the States of Rio Grande do Sul and Santa Catarina. Brazilian Society of Soil Science. Commission of Chemistry and Soil Fertility, Porto Alegre.

Schils, R.L.M., Olesen, J.E., del Prado, A., Soussana, J.F., 2007. A review of farm level modelling approaches for mitigating greenhouse gas emissions from ruminant livestock systems. Livest. Sci. 112, 240-251.

Segnini, A., Milori, D.M.B.P., Simões, M.L., Silva, W.T.L., Primavesi, O., Martin-Neto, L. 2007. Potential for carbon sequestration in pasture of Brachiaria decumbens. In: SBCS. Brazilian Congress of Soil Science, Gramado, RS.

Sejian, V., Lal, R., Lakritz, J., Ezeji, T., 2011. Measurement and prediction of enteric methane emission. Int. J. Biometeorol. 55, 1-16.

Steinfeld, H., Mooney, H., Schneider, F., Neville, L., 2006. Livestock in a Changing Landscape: Drivers, Consequences and Responses. Island Press, Washington, DC, USA.

Valadares Filho, S.C., Machado, P.A.S., Chizzotti, M.L., Amaral, H.F., Magalhães, K.A. Rocha Júnior, V.R.R., et al., 2010. Brazilian Tables of Food Composition for Cattle (Viçosa).
Veysset, P., Lherm, M., Bébin, D., 2010. Energy consumption, greenhouse gas emissions and economic performance assessments in French Charolais suckler cattle farms: model-based analysis and forecasts. Agric. Syst. 103, 41-50.

Wiedmann, T., Minx, J., 2008. A definition of carbon footprint. In: Pertsova, C.C. (Ed.), Ecological Economics Research Trends. Nova Science Publishers, Hauppauge, NY, pp. 1-11.

Wilkins, P.W., Hump, M.O., 2003. Progress in breeding perennial forage grasses for temperate agriculture. J. Agric. Sci. 140, 129-150.

\section{Acronyms and Abbreviations}

CF: Carbon Footprint

$C P$ : Crude Protein

DMI: Dry Matter Intake

DMID: Dry Matter Intake Digestibility

EFs: Emission factors

FU: Functional Unit

GWP: Global Warming Potential

Ha: Hectare

LWG: Live Weight Gain

$M C$ : Monte Carlo Analysis

MCFs: Methane Conversion Factors

NRC: Nutrient Requirements of Beef Cattle

Scenario I: Natural grass

Scenario II: Improved natural grass

Scenario III: Natural grass/ryegrass

Scenario IV: Improved natural grass/sorghum

Scenario V: Cultivated ryegrass and sorghum

Scenario VI: Natural grass supplemented with protein mineralised salt

Scenario VII: Natural grass supplemented with protein-energetic mineralised salt

TDN: Total Digestible Nutrients

Ym: Conversion Factor 